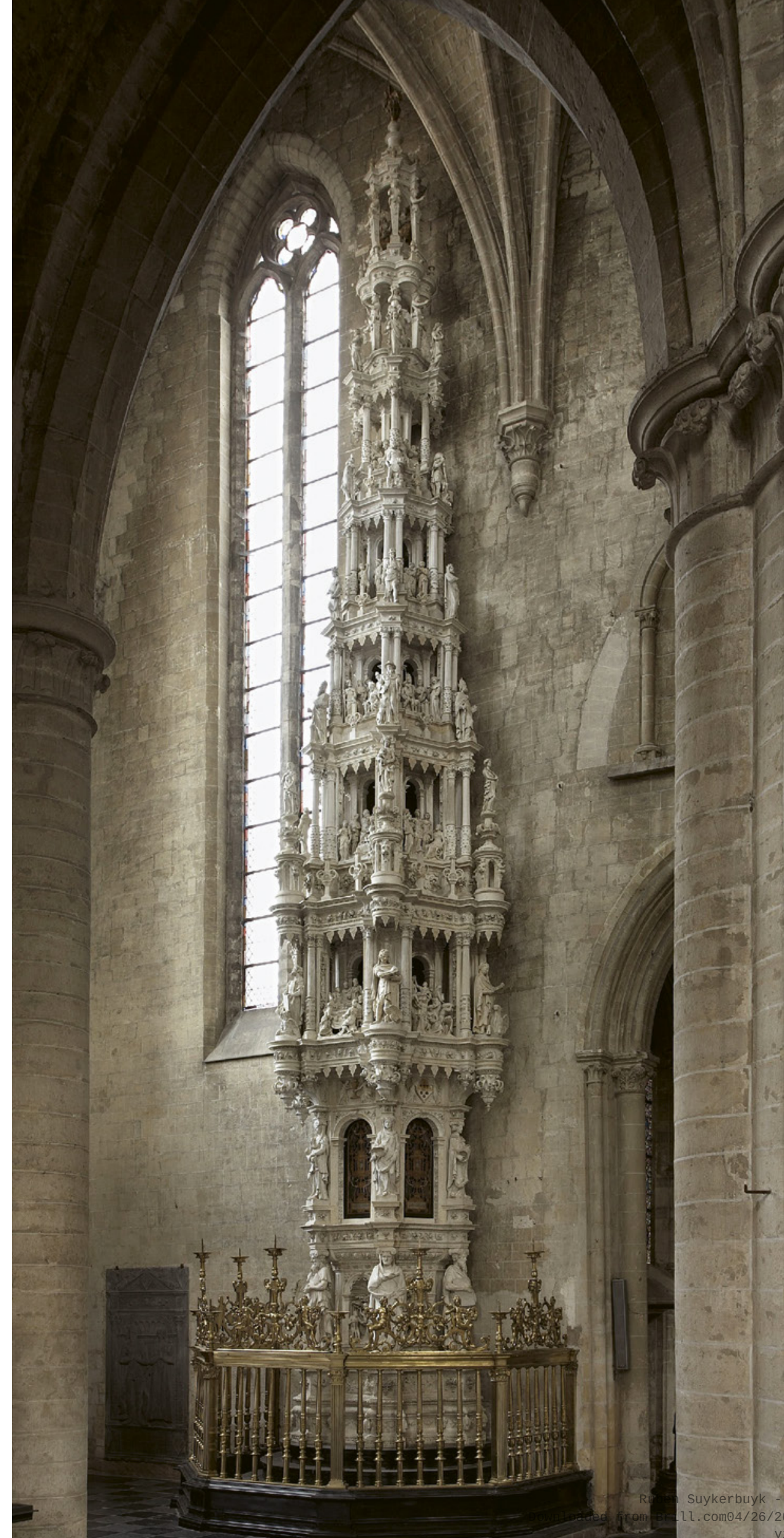




\section{0: The Waning of Medieval Piety?}

\section{Cornelis Floris' Sacrament House}

In the northern transept of the Zoutleeuw church, opposite Saint Leonard's chapel at the other end of the crossing, stands an imposing, 18-meter-high sacrament house, carved in soft white stone of Avesnes (fig. 59). ${ }^{1}$ Moving upwards across nine stories, a parade of sculpted scenes and figures sing the praises of the Real Presence of Christ in the Eucharist, which is kept behind the three metal doors of the sacrarium at the structure's third level. The elaborate iconographic program abounds in visualizations of Christian theology, and particularly highlights the sacramental symbolism of sacrifice. Five reliefs in the base show offering scenes, followed on the next story by episodes from Genesis depicting the Creation and Fall of Man. Four Old Testament prophets function as flanking atlantes, and, in a similar fashion, the four cardinal virtues stand as caryatids beside the doors of the sacrarium on the next level. One story up, the honorary parade is continued by the four evangelists standing aside classic Eucharistic prefigurations: the meeting of Abraham and Melchizedek, the Gathering of the Manna and the Last Supper. The next two stories contain figures of a whole array of saints, as well as other virtues and the church fathers. The apostles appear on the next two levels, in combination with Old Testament kings and yet other saints. These figures carry a small tempietto containing Saint Michael slaying the Devil, flanked by angel musicians, which itself serves as a base for a baldachin with the crowning of the Virgin Mary. The whole is topped by a pelican pecking its own breast to feed its young, the traditional image of Christ's sacrifice. ${ }^{2}$

A memorial stone (fig. 6o) in the immediate vicinity of the sacrament house identifies the donors of this petrified Eucharistic praise as jonker Merten van Wilre (1481/91-1558) and his wife Marie Pylipert (d. 1554), whose coats of arms occur both at the top of the stone and on the sacrament house itself, just above the doors of the sacrarium. $^{3}$ On 13 August 1550, this noble couple drew up the contract for the remarkable piece of sculpture before the Zoutleeuw aldermen. ${ }^{4}$ The commission was given to Cornelis Floris de Vriendt (1514-1575) from Antwerp, who at that moment was just embarking
FIGURE 59

Cornelis Floris, Sacrament house, 1550-1552, Zoutleeuw, church of Saint Leonard

(C) KIK-IRPA, BRUSSELS

(C) RUBEN SUYKERBUYK, 2020 | DOI:10.1163/9789004433106_005

This is an open access chapter distributed under the terms of the CC BY-NC-ND 4.o license. 


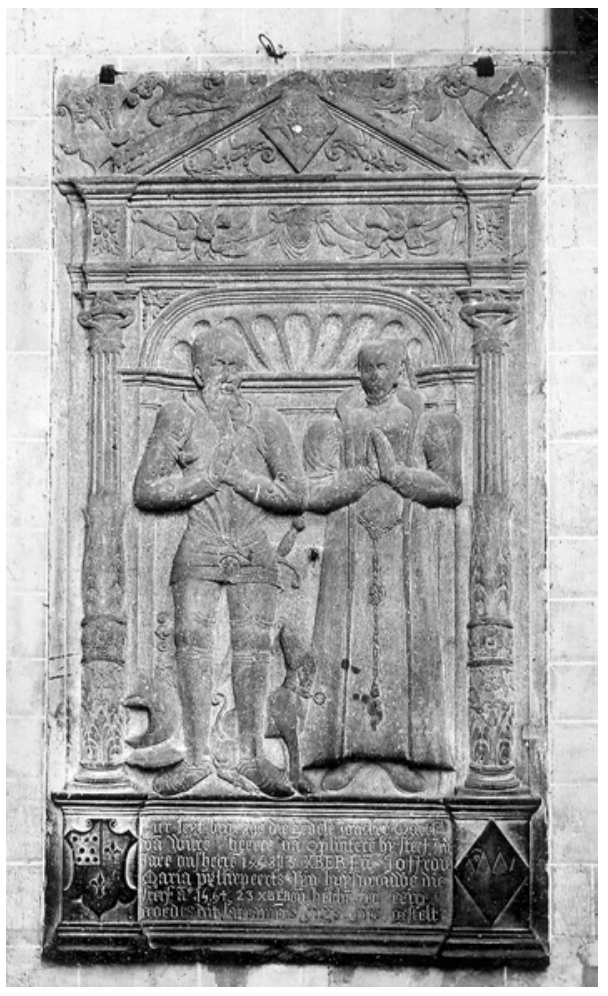

FIGURE 60

Anonymous (Leuven), Memorial stone of Merten van Wilre and Marie Pylipert, between $155^{8}$ and 1574, Zoutleeuw, church of Saint Leonard (C) KIK-IRPA, BRUSSELS

on an international career, receiving assignments to execute funeral monuments for Dorothea of Denmark (1504-1547) and her father, Frederick I (1471-1533). 5 The text laid down the financial conditions and practical arrangements for the construction, but does not provide any iconographical or dimensional guidelines, instead referring to and commenting on a previously made design (patroone), which Van Wilre had approved with his signature. A first part was to be installed by Pentecost 1551 (17 May), while Pentecost $155^{2}$ (5 June) was agreed upon as final deadline for the work. By March $155^{1}$ a part was in place, but only in October $155^{2}$ was somebody paid to unload the final stones of the sacrament house from a ship. ${ }^{6}$

Ever since the middle of the nineteenth century, the sacrament house has been one of the church's best-known showpieces. Popular overviews of the artistic treasures of the young Belgian state included prints of the structure, such as Louis Haghe's Sketches in Belgium and Germany, published in London in 1840 (fig. 61), or François Stroobant's Monuments d'architecture et de sculpture en Belgique, of which the first edition appeared in $185^{2}$ (fig. 62). The 'splendid' 


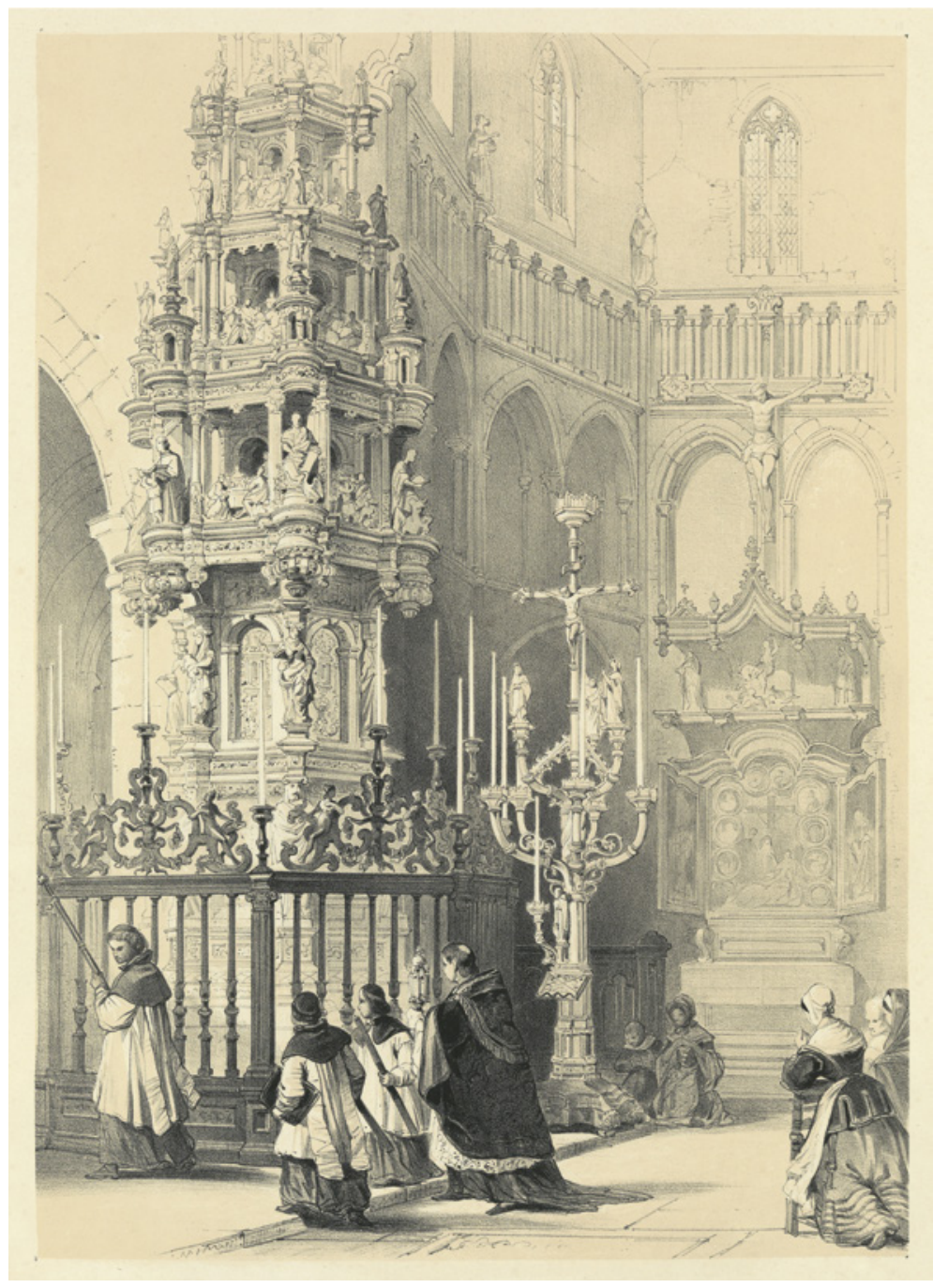

FIGURE 61

Louis Haghe, Tabernacle de l'église de Léau, from idem, Monuments anciens receuillis en Belgique et en Allemagne, 1842, Ghent, University Library

sacrament house also particularly impressed Victor Hugo during his visit of Zoutleeuw on Sunday 2 October 1864 . He had even made a special detour to see it on his way from Tienen to Leuven. ${ }^{7}$ Until the publication of the contract in 1868 identified Cornelis Floris as its maker, the work was generally thought to have been executed by a Florentine artist from the circle of Michelangelo. The fact that it figures in the major collections of plaster casts of Europe's great museums of the time, including the South Kensington Museum in London (now Victoria and Albert Museum) and the Brussels Royal Museums of Art and History (fig. 63) further illustrates its particular 


\section{FIGURE 62}

François Stroobant,

Tabernacle de l'église

Saint-Léonard à Léau, from Stroobant \& Stappaerts, Monuments d'architecture et de sculpture, 1881 , Ghent, University Library

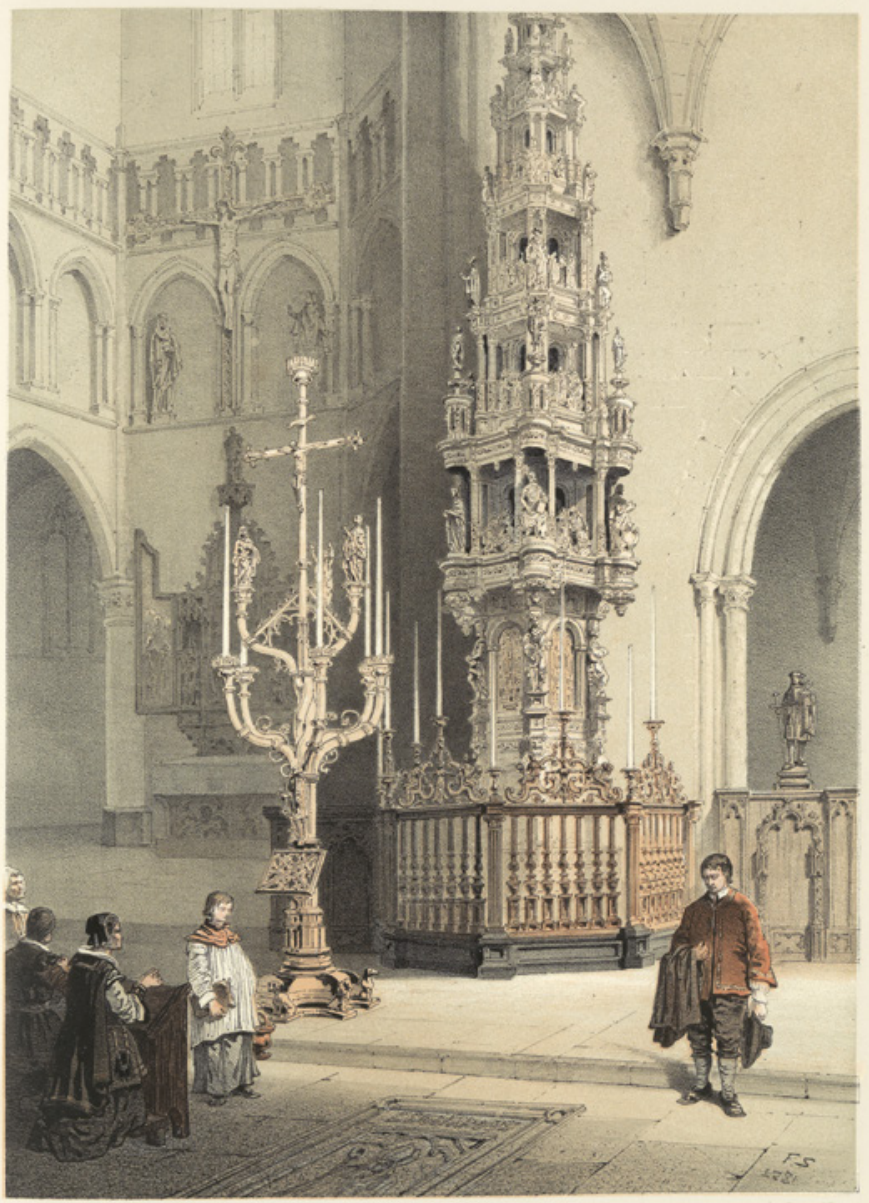

attraction. In both museums, the cast from the 1870 s takes a place of honor beside internationally still renowned sculptural works like Trajan's column and Lorenzo Ghiberti's Gates of Paradise.

In the sixteenth century, such a sacrament house was hardly unique, however, as they were firmly rooted in medieval tradition. The Fourth Lateran Council (1215) had defined the doctrine of the Real Presence: a key element in Catholic theology which taught that the transforming rite of Mass rendered Christ physically present in the communion bread and wine, which would so literally be visualized in the iconographic theme of the Mass of Saint Gregory (Chapter 2). The consecration thus turned the hosts into relics of Christ. The doctrine and the subsequent institution in 1264 of the Feast of Corpus 


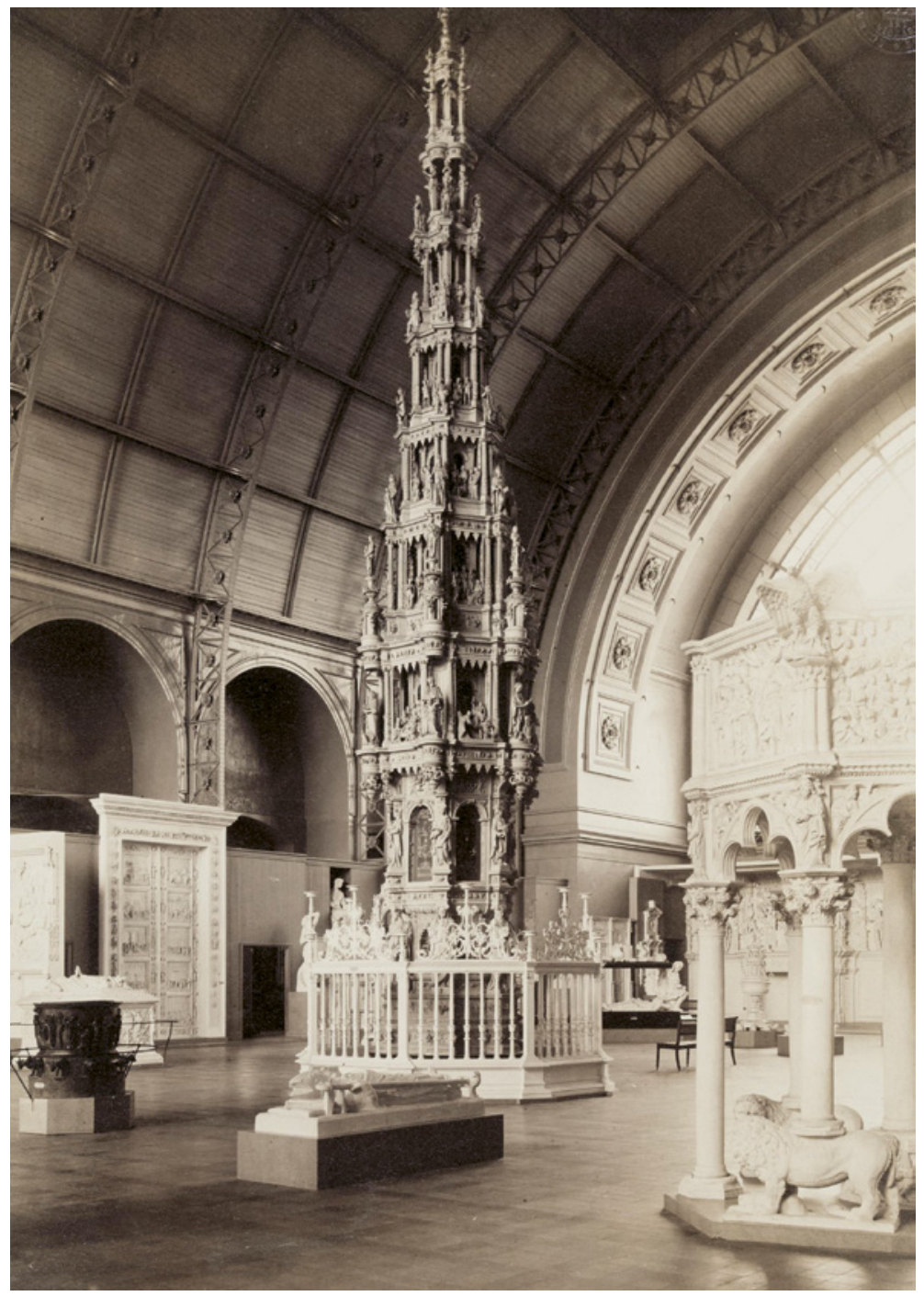

Christi, first in the Prince-Bishopric of Liège of which Zoutleeuw was a part, led to an intense veneration of the consecrated host in the Low Countries. ${ }^{8}$ From the fourteenth century onwards this found its most fascinating expression in a series of cults of miraculous hosts, which had reportedly turned into flesh or started bleeding. In Niervaart such a cult already existed around 1300, and when it was moved to Breda in 1449 miracles continued to be reported. From 1327 onward the Abbey of Herkenrode could also boast a miraculous host. Arguably the best-known example is the Holy Sacrament of Miracle of Brussels, a set of hosts that reportedly went bleeding after
FIGURE 63

Plaster cast from Cornelis

Floris' sacrament house in Zoutleeuw's church of Saint Leonard, c. 1876, Brussels, Royal Museums of Art and History

(C) KIK-IRPA, BRUSSELS 
FIGURE 64

Anonymous, Wall

tabernacle, c. 1500 ,

Havré, chapel of

Saint-Antoine-en-

Barbefosse

(C) KIK-IRPA, BRUSSELS

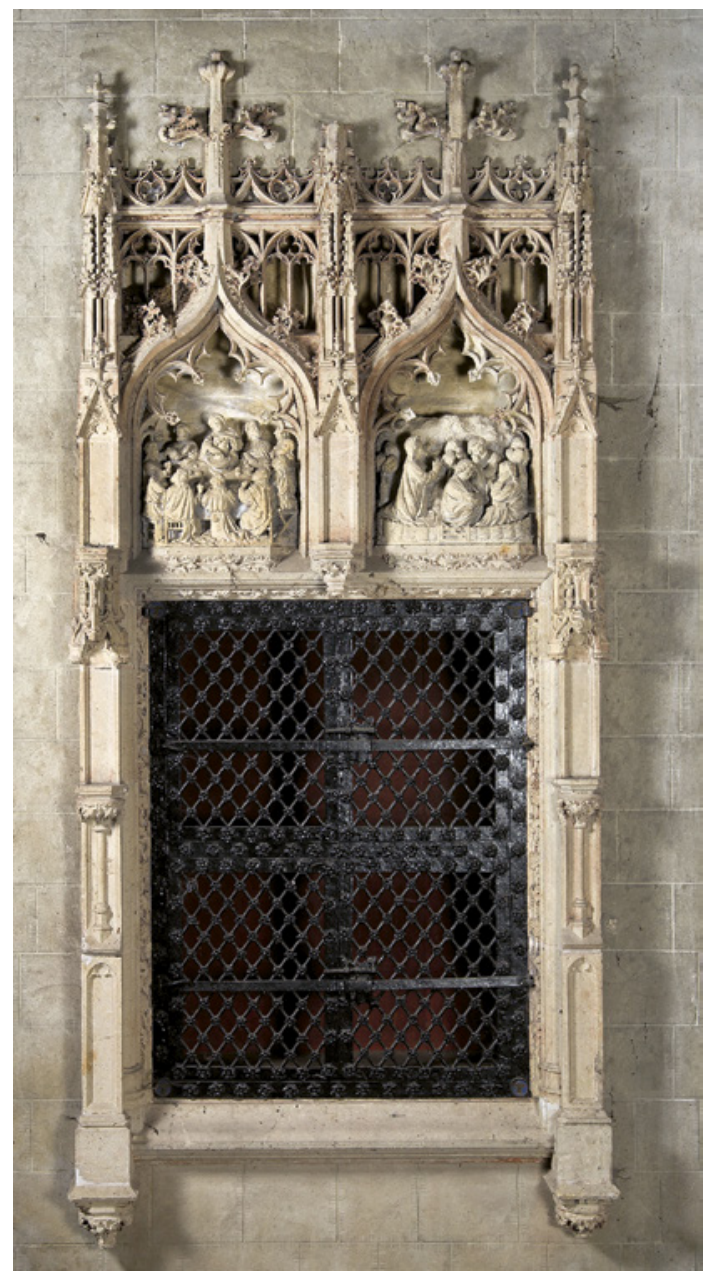

having been stabbed by Jews in 1370, kept in the church of Saints Michael and Gudula. Soon after, in 1374, a miraculous host was also revealed in Middelburg. It was later sent to Cologne and then, in 1380 , to the Augustine convent in Leuven. In 1405, finally, the abbey of Bois-Seigneur-Isaac saw a Eucharistic miracle that meant the start of an important cult. ${ }^{9}$ Apart from this limited number of miracle cults with a broad geographic importance, from the late fourteenth century onwards many towns also developed their own Corpus Christi processions, in which the civic community paraded the consecrated host through the streets. ${ }^{10}$

As the host was considered a relic, every church also had to protect and appropriately preserve these sacred remains from Mass. Initially it was stored on the altar itself, but from the twelfth century onwards 
it was gradually moved into separate locked cabinets at the side of the altar. Around the same time as the Eucharistic miracle cults were instituted, these precious containers that both protected and displayed the Eucharist grew in size and monumentality, and they were often decorated with lavish ornamentation and iconography. From the late fourteenth century onwards two basic types existed, which were both quite consistently referred to as (heylich) sacramentshuys in Middle Dutch, mayson du Saint Sacrement in French or sacrae eucharistiae domicilium in Latin. ${ }^{11}$ On the one hand the traditional wall tabernacle remained in use, such as in Havré (fig. 64, compare with fig. 44). On the other hand these cabinets evolved into independent structures, detached from the church wall. The latter were mostly constructed in stone, but examples in metal have survived as well (fig. 65).

These independent, micro-architectural and tower-like sacrament houses could be found all over the broad Germanic region in Europe, but most examples have been preserved in central Europe and the Baltic, with Ulm (c. 146o-1470) and Nuremberg (1493-1496) being the most famous examples. ${ }^{12}$ In the Low Countries, by contrast, as a result of the religious upheavals in the sixteenth century, later alterations of church interiors, and destructions in World Wars I and II almost no sacrament houses remain today. The oldest and most famous sacrament house preserved in the Low Countries was commissioned from Mathijs de Layens by the Confraternity of the Blessed Sacrament for the church of Saint Peter in Leuven around 1450 (fig. 66). ${ }^{13}$ Similar, independent sacrament houses reached their height as an essential feature in most churches in the fifteenth and first half of the sixteenth centuries. They were either freestanding or positioned against a wall, but always on the evangelical side, i.e. to the north of the high altar. Reservation of the consecrated host on the main altar was rare before the Tridentine reforms: Jean Mone's 1533 formal experiment in his Retable of the sacraments at Halle (fig. 67), which is crowned by a sacrarium and originally functioned as main altar, provided an important artistic precedent for post-Tridentine structures, but remained virtually unique throughout much of the sixteenth century. ${ }^{14}$

While most of the known sacrament houses in the Low Countries and Germany are gothic in design, the Zoutleeuw structure is striking for its all'antica appearance. Instead of the complex geometric ornamental language so typical for gothic structures, Cornelis Floris' example follows classical architectural orders and is furnished with antique decorative elements, such as caryatids, herms and garlands. 
These outer stylistic characteristics must not, however, obscure the gothic essence of the piece. In fact, the sacrament house is a transitional work of art. Its typological form is rooted in a vivid medieval devotional culture, in which the Eucharist and its material cult were central (Chapter 2). It is, moreover, still essentially gothic in its marked verticality, which differed from the more horizontally conceived Renaissance style in which Floris usually worked, and in which Jean Mone, for instance, had designed his Retable of the sacraments nearly twenty years earlier. ${ }^{15}$ Floris' creation thus balances tradition and innovation, consciously playing with both. How does this observation tie in with the traditional narrative on the evolution of piety and religious patronage in the sixteenth-century Low Countries after the introduction of Protestant thought? 1520 has been characterized as a moment of dramatic disruption with the preceding period; it has even been proclaimed the end of the Middle Ages. However, material sources such as the Zoutleeuw sacrament house, commissioned right in the middle of this period of supposed devotional decline, suggest an alternative, more complex story wherein continuity played a much more important role than previously thought. It encourages a reconsideration of the traditional view of a waning medieval piety. In what devotional context was the sacrament house installed, and what did it mean to commission such a monumental structure in the Low Countries of the 155 os? What did ' 1520 ' really signify for religious life and its accompanying material culture in the Low Countries during subsequent years?

\section{The Introduction of Protestant Thought}

The years surrounding ' 1520 ' certainly were eventful in the Low Countries. Not long after Martin Luther had caused a stir in Saxony with his 95 theses on the sale of indulgences by the Church of Rome, the reformer's writings and his ideas also reached the Habsburg territories. Around the beginning of 1519 a set of his publications arrived in the university town of Leuven, where the professors of the theological faculty would soon engage in a penetrating inquiry. After having consulted their colleagues from the university of Cologne, on 7 November 1519 the Leuven faculty unanimously condemned Luther as heretic and in February 1520 their denunciation was published by Dirk Martens. Only in the course of the following months would a reaction from Rome follow, when Pope Leo x obliged the 


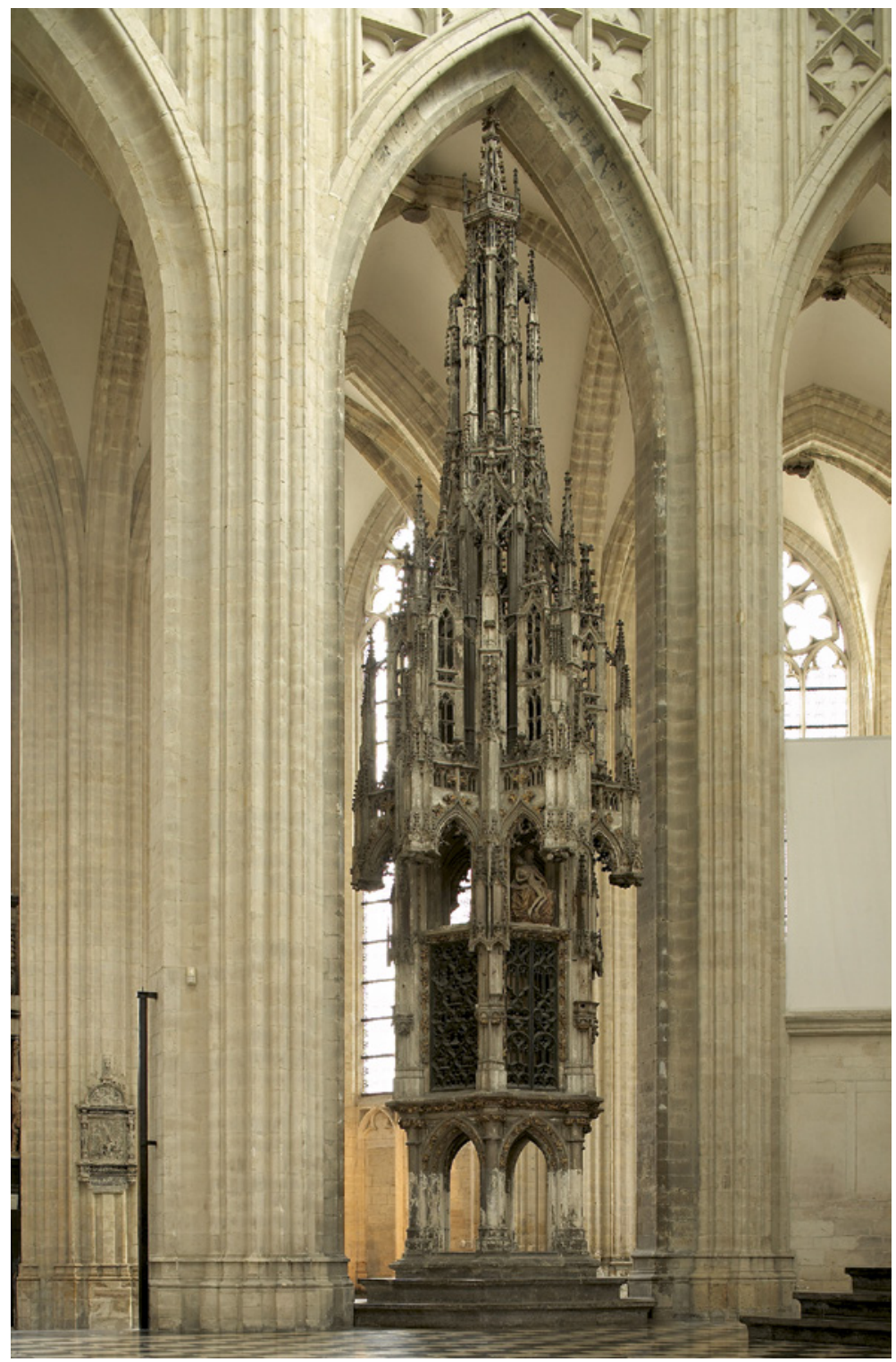

Saxon reformer to revoke his teachings with the bull Exsurge Domine, issued in June $1520 .{ }^{16}$ Meanwhile, the debate had already burst out of the boundaries of the university, and in November 1520 a Middle Dutch translation of Luther's writings on indulgences circulated in Antwerp. ${ }^{17}$ The commercial metropolis soon took up a leading role in the early history of the Reformation in the Low Countries, especially by the activities of the local Augustinian friars. After their
FIGURE 66

Mathijs de Layens,

Sacrament house, c. $145^{\circ}$,

Leuven, church of

Saint Peter

(C) KIK-IRPA, BRUSSELS 
FIGURE 67

Jean Mone, Retable of the sacraments, 1533 , Halle, basilica of Saint Martin (C) KIK-IRPA, BRUSSELS

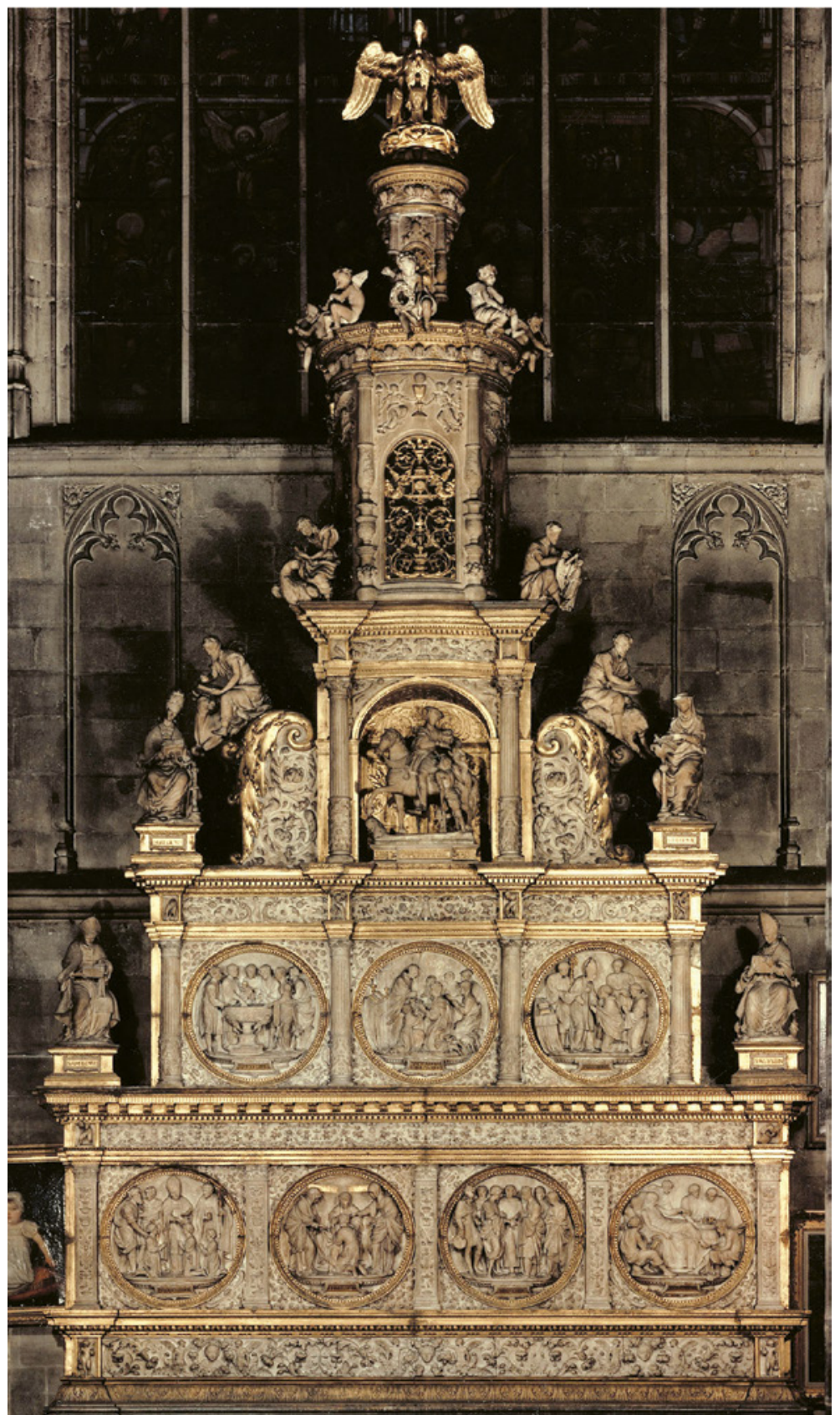

convent had been abolished and demolished on imperial command, on 1 July 1523 the friars Hendrik Voes and Jan van Essen were publicly burned at stake on the central market square in Brussels. They went down in history as Europe's first Protestant martyrs. 
The gruesome execution did not keep Luther's ideas from spreading, however. When the papal nuncio Hieronymus Aleander arrived in the Low Countries in 1520 to enforce the observation of Exsurge Domine, he assessed the situation as being a very dangerous one. He organized public book burnings in Antwerp, Leuven and Ghent, and all over Flanders trials soon followed in the course of the $15^{20} .^{18}$ In Utrecht, the cathedral churchwardens provided their quaestores with printed texts that condemned Luther's ideas, which they held partly responsible for the decline in devotional revenues they had noted in ${ }^{1522 .}{ }^{19}$ Best known in art historical scholarship is the 1527 trial held in Brussels against court artists Bernard van Orley, Pieter de Pannemaeker and others, who were also referred to as lutheriaenen. ${ }^{20}$ Luther's ideas were indeed an important impetus for the Reformation, but the movement at large also drew heavily on the Christian or biblical humanism that had preceded it, with major thinkers such as Erasmus as central figures. Very soon the dynamics in the Low Countries would indeed go far beyond the mere influence and ideas of Luther himself. In these early years 'Lutheran' was used as a general but imprecise umbrella term, because soon other reformers would start spreading yet other heterodox ideas. Anabaptists, Calvinists and many other religious groupings on the Protestant spectrum would gain ground in the Low Countries through increasing organization. ${ }^{21}$ As a result, during much of the sixteenth century the Low Countries were de facto typified by religious pluralism. Alastair Duke has rightly emphasized the 'protean character' of the early phase of the Reformation in the Habsburg territories, which was characterized by excitement, experiment and chaos. ${ }^{22}$

Chaos and literal destructions were yet other indications of the debates stepping out of the walls of universities and 'popish' institutions, as the spreading of Protestant ideas throughout Europe was soon accompanied by iconoclasm. Building on a long-standing tradition in Western culture with important roots in Antiquity and the Byzantine Empire, and resurfacing endemically well into the fifteenth century, iconoclasm became inextricably bound up with the Reformation from the 152 os onwards. The Wittenberger Unruhen of late January 1522 are traditionally considered as the starting point of Protestant image-breaking: in response to Andreas Bodenstein von Karlstadt's tract Von abtuhung der Bylder and to popular demand, the city council of Wittenberg decided to do away with images in churches. These actions actually disappointed Luther, who had himself taken a much more moderate stance on the issue of images. In 
a similar way, after popular attacks on religious objects in Zürich in September 1523 , the magistracy organized a widely attended public debate on the matter of images in which Zwingli defended the harshest position. ${ }^{23}$ In the slipstream of Protestant reform, iconoclasm followed all over northern Europe: in Scandinavia (1530s), in England (especially between 1547 and 1553), in Scotland (from 1559 onwards) and in France (most violently between 1559 and 1562). ${ }^{24}$ In the Low Countries a series of intense iconoclastic attacks succeeded each other in the course of August, September and October 1566 (Chapter 7). ${ }^{25}$ This Beeldenstorm or Iconoclastic Fury hit almost all of the provinces of the Habsburg Netherlands in an impressively short time span, but many examples demonstrate that the destruction of sacred objects was by no means an unknown phenomenon prior to 1566 (Chapters $4 \& 5$ ). In fact, the decades following 1520 can certainly be called iconoclastic times. News about such events was increasingly available in cities and towns all over Europe due to networks which had developed on an international scale. ${ }^{26}$ In addition to the occasional iconoclasms in the Low Countries, its inhabitants must have certainly also heard of the other conflicts throughout Europe. This means that the more encompassing debate, which was essentially about the materiality and physicality of traditional devotion that appeared so central to late medieval piety (as discussed in (Chapters 1 \& 2), was certainly not limited to university or humanist circles alone. The debate was public.

\section{The 1520-Thesis}

As the community at large was involved in these discussions in significant ways, it is essential to look beyond theological writings in order to consider how Protestantism actually influenced lay piety. However, this common, lay Catholic perspective has only been taken into account to a limited extent in the scholarship on piety and religious material culture in the sixteenth-century Low Countries. Moreover, this literature has mostly looked for changes rather than for possible continuities. Whereas heterodox groupings have been studied in many respects, the perspective on the Catholic situation in the Low Countries has mostly focused on decline. To a significant extent this can be traced back to Toussaert's daunting 1963 assessment of late medieval piety. The portrait he painted was damning and he could only conclude that the Reformation had been smoldering for a long time, that it was inevitable and necessary. ${ }^{27}$ 
Religious studies from the 1980s onwards took up Toussaert's methods to map devotional transformations. First and foremost, Wim Vroom conducted an in-depth and long-term case-study of Utrecht cathedral in an approach that differed from Toussaert who had used scattered material from all over Flanders in non-continuous sequences. Analyzing various revenues throughout the fifteenth and early sixteenth centuries, Vroom found significant changes in the early 1520 . The revenues from diocesan collections that had grown to become an important source of income for the cathedral quite suddenly and nearly completely fell away after 1525 . The collegiate chapter noted, with great disappointment, that 'the glow of ancient piety has cooled off and nearly smothered in these bitter times'.28 A few years before, in 1522, Luther himself had already been blamed as one of the causes, but it is important to emphasize that the chapter at the same time also saw the raging wars and economic crisis as equally important characteristics of what they defined as bitter times. ${ }^{29}$ Vroom later discovered similar developments for Antwerp's church of Our Lady, where he identified 1522 as turning point. The decline was much more gradual, but the devotional offerings clearly diminished, and Vroom explained this a a result of the religious crisis that Luther had initiated..$^{30}$ Much as was the case in Utrecht, the churchwardens of Antwerp's church of Saint Jacob had complained to Charles $\mathrm{v}$ that the offerings had gravely diminished ever since Luther's teachings were spread in the city. ${ }^{31}$

Guido Marnef later confirmed these general trends for the whole metropolis on the river Scheldt, and furthermore added that after 1520 almost no new confraternities and chaplaincies were founded. ${ }^{32}$ In a similar vein, Verhoeven's study of late medieval miracle cults in Delft included an analysis of their revenues, and again presented 1520 as an 'abrupt' end point. He even went so far as to call it a 'total collapse.' ${ }^{33}$ Paul Trio's findings were along the same lines. He extensively investigated the origins, developments and functioning of confraternities in late medieval Ghent. As far as his material allowed him to make conclusions on the matter, he saw a 'general and drastic decline of the number of new members in the second quarter of the sixteenth century'. ${ }^{34}$ He later ventured another general study of the evolution of anniversary Masses wherein he again noted a decline in the number of foundations from around 1520 onwards. $^{35}$

Together these studies established a still generally accepted narrative of a rapid decline of Catholic devotion in the Low Countries after 1520 . Their conclusions resembled Toussaert's characterization 
of late medieval piety as forewarning an inevitable Reformation. The 'sudden' implosion of devotion was considered as marking the end of an era. Presented in this way, the material was indeed highly compatible with Protestant critiques: offerings and investments in chantries diminished, pilgrimage sites reportedly became less popular, membership numbers of religious confraternities dwindled, convents attracted fewer vocations and were openly criticized. Taken together, these observations came to be known as the $15^{20}$-thesis, proclaiming that this year represented a crucial turning point for religious life in the Low Countries. Alastair Duke concluded that it marked a 'profound transformation' in the religious expressions and behavior of both laypeople and clerics. ${ }^{36}$ Koen Goudriaan even went so far as to rhetorically declare it as the end of the Middle Ages, and he spoke of a veritable 'crisis in religious behavior'. ${ }^{37}$ From this perspective, the Beeldenstorm of 1566 was no more than a logical consequence of the widespread aversion to traditional Catholicism in general and its material devotion in particular. Pollmann brought some more nuance to this point when she established that many lay Catholics did resent this course of events, but remained passive vis à vis Protestant critiques as they were convinced that 'each should tend his own garden'. ${ }^{38}$ In general, however, the account remained the same.

\section{Problems}

The argumentation is problematic. Annemarie Speetjens has already pointed out that a lot of material that does not fit into the general narrative is often left out of the discussion. She cites examples of confraternities in Ghent in 1485, Bergen op Zoom in 1489 and 's-Hertogenbosch in 1510 that already documented diminishing members before the introduction of Protestant thought, while similar organizations in Heusden and the Utrecht Buurkerk, for instance, enjoyed continued popularity until the middle of the sixteenth century. ${ }^{39}$ Many more examples can be cited here. Kruisheer also observed a diminishing number of bequests and memorial Masses in the Confraternity of Our Lady in Doesburg (Duchy of Guelders), already around $1510 .{ }^{40} \mathrm{~A}$ similar pattern was discerned in late medieval Lier. Although no churchwarden accounts have been preserved for the period between 1509 and 1547, Meuris argues that monetary offerings, gifts in kind and the sale of pilgrim badges reveal a boom between 1476 and 1490, followed by a decline from around 1490 and $1495 .{ }^{41}$ Contrary to Trio's observations, no decline in the number of founded anniversary Masses can be discerned around 1520 in the 
Ghent parish of Our Lady, and in Kortrijk a decline in the cult of saints is only notable around $1540 .{ }^{42}$ The case of Turnhout, a town in the rural Campine area, is particularly interesting. Quantitative analysis of the churchwarden accounts reveal that after 1520 considerable fluctuations occurred in the revenues from collections. Moreover, the founded anniversary Masses between 1398 and 1574 certainly show no linear downfall, but rather a cyclical pattern over the years. $^{43}$

Furthermore, the documentary evidence that has been used to support the 1520 -thesis almost exclusively comes from highly urbanized contexts. In the early sixteenth century, Antwerp was one of the largest cities in Europe. Cities such as Ghent and Utrecht followed in its wake and counted among the largest cities within the Low Countries. Delft, too, had around 10,00o inhabitants or more in 1514 and thus was one of the principal cities in the highly urbanized County of Holland. ${ }^{44}$ It goes without saying that such large urban entities had other dynamics than smaller towns and villages. After all, the Reformation has often been characterized as an essentially 'urban event'. 45 This insight should remind scholars of the risks of rash extrapolations. Nevertheless, cities such as Antwerp have all too often been taken as textbook examples for developments elsewhere and the 1520 -thesis has also been used to explain developments in non-urban areas. In his study of Wezemaal, for instance, Minnen assumed that there was a 'collapse' of the cult after 1520 . There is only limited material to support such a claim, however, and it is only financial in nature. Furthermore, many pilgrims came from out of town, so the developments do not necessarily tell us about the situation in Wezemaal itself. In any case, in 1559 the parish priest reported that he knew of no heresies among his flock. 46

Virtually no research has yet been conducted on the religious developments throughout the sixteenth century in more rural areas, but it has already been supposed that they remained more or less untouched by Protestant ideas. Both Juliaan Woltjer and Johan Decavele have argued that in the Low Countries Protestantism only settled firmly in larger cities or areas characterized by welldeveloped industrial infrastructure, whereas traditional ideas and practices comparatively remained stronger in the rural areas. ${ }^{47}$ This statement remains to be verified, but recent research on the rural Veluwe area in the Duchy of Guelders confirms this view. Until the early seventeenth century the implementation of the Reformed religion met with fierce resistance there, as both the rural population and the local nobility refused to give up Catholicism. ${ }^{48}$ In the 
Bishopric of Liège - of which Zoutleeuw was part until the reforms of 1559 - the influence of Protestantism also appears to have been limited. This does not seem to have been the consequence of placards or an active policy of repression as was the case in many of the Habsburg territories. There were only a few persecutions, and executions of heretics rarely if ever caused tumult. ${ }^{49}$

The chronological scope and the historiographical frame within which the events are interpreted are equally of crucial importance. The 1520 -thesis is essentially part of a narrative that is firmly rooted in the stereotypical pessimistic views of late medieval piety that have been discussed in the Introduction. Most problematic is the ambivalent position of the fifteenth century in the historiography on the subject, as it is treated as either an epilogue or prologue, depending on the main field of interest. John Van Engen has elaborately established that this is at odds with the period's own rich idiosyncrasies, seeing a multiplication and diversification of pre-existing practices, which resulted in intense lay participation - a view that has been confirmed in Part 1 of this book. ${ }^{50}$ With the exception of Marnef, whose principal subject was the development of Protestantism in Antwerp, the $15^{20} \mathrm{O}$-thesis has mostly been propagated in studies that were chronologically limited to the Middle Ages. From this angle, $15^{20}$ appeared as a convenient end point. History is continuous, however, and termini are always scholarly constructs that often serve rhetorical purposes.

\section{Alternatives}

A long-term study of Zoutleeuw thus provides a valuable, complementary case that allows us to chart the evolution of lay devotion and its material culture after 1520 . Located in the relatively rural Bishopric of Liège rather than the more urban bishoprics of Tournai, Cambrai and Utrecht, the town had lost much of its previous importance by 1520 . Like the surrounding Hageland region of which it was part, the town was in economic decline, and this clearly had a negative impact on demography. ${ }^{51}$ With about 2000 inhabitants around $15^{20}$, the Zoutleeuw context certainly was very different from that of Antwerp, Delft, Ghent and Utrecht. A large chronological scope, transcending traditional categories of historical periodization further contributes to overcoming existing bias. Scholars such as Francis Rapp have already emphasized the necessity of studying the events framing the Reformation on a long-term basis. ${ }^{52}$ It is indeed impossible to define 1520 as a caesura without studying the preceding and succeeding periods, but such an approach has never 
been put into practice where the Low Countries are concerned. The documentary evidence of the preceding 70-year period, presented in Part 1, allows us to re-evaluate this thesis. The years immediately preceding Luther's activity were characterized by a strikingly intense piety and a devotional boom that was manifested in different ways: miracles increasingly occurred at newly established shrines, as a result of which the cult circuit appears to have condensed and the indulgence system was successful to an extent that had not been seen before.

This devotional boom is not only apparent in Zoutleeuw's source material, but ironically also in the material that has been advanced to support the 1520 -thesis. For instance, it has been pointed out that in the city of Antwerp, the important cult of the image of Our Lady 'on the stick' ( op 't Stokske) saw a considerable decline from the early 1520s. It has, however, not sufficiently been emphasized that the cult was of a relatively recent origin, as the statue had only started to work miracles in $1474 .{ }^{53}$ Only from that year onwards have individual accounts of the cult been preserved, starting with the account documenting the installation of the stick in question. ${ }^{54}$ Marnef's graphs charting the cult's devotional revenues show a steady rise in the later years of the fifteenth century, with a peak around 1490, after which they actually already start to diminish in absolute terms. The same pattern recurs elsewhere in the Antwerp context. The total devotional revenues in the Antwerp church of Our Lady show a parallel evolution, again with an unprecedented peak around 149o. The same can be deduced from other findings by Marnef: while he points at the chronological evolution of the foundation of confraternities and chaplaincies in Antwerp to illustrate the decline after 1520, he places less emphasis on the fact that the years around 1500 stand out as the absolute high point. ${ }^{55}$

Similarly, as we have seen, Vroom established that the revenues from the diocesan collections almost completely fell away after 1525, but it should be noted that his data also clearly show a steady rise throughout the fifteenth century, reaching climaxes in 15 oo and 1525 itself. ${ }^{56}$ The same can be said of the confraternities in Ghent studied by Trio. They illustrate that the later fifteenth century saw the absolute high point of memberships, which for some confraternities lasted until $1525 .{ }^{57}$ While these observations do not counter the argument that there was a devotional decline after 1520 that has been presented by scholars, they do shed a different light on these developments. The perceived sudden - or in some cases not so sudden drop after 1520 is not absolute, but relative. Although it is possible 
to speak of decline, it is only a decline when contrasted to the high peak that preceded it. Thus, and this is central to my argument, both moments cannot be studied separately, but should be considered in interaction.

This long-term approach with which this book proposes to study the events around 1520 should also be applied to the succeeding period. Scholars have been quick to emphasize that the drop noted circa 1520 revealed a definitive rather than a temporary phenomenon. Not all cases confirm this, however. For instance, after a devastating fire in the Antwerp church of Our Lady in 1533 the devotional revenues rose again, and though they would not reach the exceptional level of around 1490 again, they nevertheless remained on a significant level until $155^{2}$ at least. The same has been noted in the case of the Delft churches. ${ }^{58}$ These examples suggest that at least some citizens continued to care for their church buildings, regardless of the spread of Protestantism and growing criticism on the Church of Rome. This is further corroborated by the increasing popularity of lotteries being organized to finance major church building projects, grosso modo between 1520 and $1560 .{ }^{59}$ Protestantism had apparently not yet conquered the minds of the parishioners to such an extent that they conscientiously refused to donate money to the church. Finally, a long-term approach also allows us to chart possible transformations of piety. ${ }^{60}$ Henry Dieterich, for instance, found that confraternities in the city of Liège took on different forms of piety precisely at the moment when the distinction between Protestant and Catholic became crucial. ${ }^{61}$ Such observations are crucial for an understanding of religious material culture in the sixteenth-century Low Countries.

\section{Continuities}

The examples discussed above suggest that thinking cyclically about forms of piety and the popularity of cults can prove to be rewarding and more in tune with the documentary evidence. Cyclical patterns similar to those identified with regard to the cult of Saint Leonard in Zoutleeuw (Chapter 1) have been proposed by Geary, who noted 'considerable fluctuations in both the short and the long term' in the cult of relics in the Middle Ages. ${ }^{62}$ By contrast, the devotional developments in the sixteenth-century Low Countries have generally been interpreted in terms of disruption. Recently, however, historical studies of piety in early modern Europe have started to 
look more closely at continuities, pointing to the continued attachment of believers to traditional religious practices. ${ }^{63}$ Bossy's pan-European view on Christianity in the West between 1400 and 1700 has recently been confirmed by Caroline Walker Bynum and Constantin Fasolt, who similarly argued that the Reformation was not the radical and decisive break with the Middle Ages it often is thought to have been. ${ }^{64}$ Regional studies by Neil Galpern for France and Eamon Duffy for England, among others, have illustrated the tenacity of what Duffy labelled 'traditional religion'. ${ }^{65}$ A similar continuity in traditional devotional practices has also been noted by Llewellyn Bogaers with regard to Utrecht and by Jos de Weerd on the Veluwe region. ${ }^{66}$

It is interesting to note that heterodox perspectives have also drawn attention to continuities, stressing the clear links between late medieval heresies and the earliest Protestants in the Low Countries. Persecutions were certainly no new phenomenon when the first Protestant martyrs were burned at the stake on the Brussels market square. Moreover, Alastair Duke has pointed out that the same imagery and metaphors continued to be used. ${ }^{67}$ Luther's critique in his 95 theses of 1517 was focused on the indulgence system, but as has been signaled in Chapter 2 that was a phenomenon nearly as old as the system itself. Furthermore, iconoclasm also had clear precursors. Walker Bynum, among other scholars, has argued that late medieval iconoclasm actually developed in parallel to the increasing popularity of lifelike images. ${ }^{68}$ Still in the later sixteenth century, the Leuven theologian Johannes Molanus referred to a medieval tradition whereby images of saints were humiliated if the requested miracles failed to occur. ${ }^{69}$ Although it is tempting, in light of these arguments, to link the $15^{25}$ complaint of the Utrecht cathedral chapter that 'the glow of ancient piety has cooled off' to the spreading of Luther's teachings, such utterances are put in perspective when read aside of episcopal complaints in Tournai that use nearly exactly the same wording but date about 15 o years before. ${ }^{70}$

These recent studies question the stereotypical image of the sudden breakdown of traditional religion around 1520 marking the end of the long and dark Middle Ages, and suggest that actual practices were far more continuous with previous periods. The following chapters will confirm these observations by closely analyzing how the religious developments in the Low Countries impacted religious material culture in Zoutleeuw, where continuity is materialized through the sacrament house commissioned by Merten van Wilre 
and Marie Pylipert. The religious convictions and moral values of a wealthy nobleman and his wife may of course not have been the same as that of a journeyman whose fortunes were much less certain. Nevertheless, in an effort to keep the social scope of this study as broad as possible, the local elite will be treated alongside the other categories of pilgrims and parishioners. None of these groups are of course strictly defined social categories, and overlaps certainly existed: while the cult of Saint Leonard in Zoutleeuw doubtlessly drew, in large part, on the local population, patrons such as Merten van Wilre were evidently also an integral part of the parish community, and they might equally have undertaken pilgrimages. But distinguishing between groups allows us to focus on different aspects of the broad religious material culture, thus overcoming the documentary limits related to the study of traditional piety. After all, there was usually little reason to register the orthodox point of view, in contrast to the rich judicial sources produced by the persecution of heresies. Zoutleeuw's representativeness will be measured by contextualization through comparative analysis of cases located elsewhere in the Low Countries. This also allows us to discern motives and intentions. Did the Zoutleeuw community engage in a dialogue with heterodox views, and how should continuity consequently be assessed: as an unconscious continuation of religious practices, or as their conscious confirmation? 